\title{
Kesiapan guru matematika sekolah menengah pertama dalam melaksanakan Kurikulum 2013
}

\author{
K. Khikayah \\ SMP Negeri 1 Satu Atap Kampung Laut. Kelurahan Panikel, Cilacap, Jawa Tengah 53259, Indonesia \\ Corresponding Author. E-mail: ykhikayah@yahoo.com \\ Received: 13 September 2018; Revised: 17 September 2018; Accepted: 21 September 2018
}

\begin{abstract}
Abstrak
Penelitian ini bertujuan untuk mengungkap kesiapan guru matematika SMP negeri di Kabupaten Cilacap dalam melaksanakan Kurikulum 2013. Penelitian ini merupakan penelitian deskriptif eksploratif dengan menggunakan pendekatan kuantitatif dan kualitatif. Dengan menggunakan teknik stratified purposive sampling, 34 guru matematika dipilih sebagai sampel dari total 264 guru matematika SMP di kabupaten Cilacap, Jawa Tengah. Pengumpulan data dilaksanakan melalui angket, wawancara, observasi, dan dokumentasi. Hasil penelitian menunjukan bahwa kesiapan guru matematika SMP negeri di Kabupaten Cilacap termasuk kriteria cukup. Kesimpulan tersebut didukung oleh komponen: pengetahuan guru tentang pembelajaran matematika Kurikulum 2013 yang termasuk kriteria cukup; upaya yang dilakukan guru untuk meningkatkan pemahaman terhadap pembelajaran matematika Kurikulum 2013 yang termasuk kriteria kurang; sikap guru terhadap pelaksanaan Kurikulum 2013 yang termasuk kriteria cukup; perencanaan pelaksanaan pembelajaran matematika yang sesuai dengan Kurikulum 2013 yang termasuk kriteria cukup; dan ketersediaan sarana dan prasarana sekolah yang menunjang pelaksanaan Kurikulum 2013 yang termasuk kriteria kurang.
\end{abstract}

Kata Kunci: kesiapan guru, pembelajaran matematika, kurikulum 2013

\section{The readiness of mathematics teachers of state junior high schools to implement Curriculum 2103}

\begin{abstract}
This study aims to reveal the readiness of mathematics teachers of state junior high schools (SJHS's) in Cilacap Regency in implementing Curriculum 2013. This study was a descriptive eksplorative that used the quantitative and qualitative approach. Using the stratified purposive sampling technique, 34 mathematics teachers were chosen as a sample of a total of 264 junior high school mathematics teachers in Cilacap district, Central Java. The data were collected through questionnaires, interviews, observation, and documentation. The data were analyzed using the quantitative and qualitative descriptive techniques. The results of the research show that the readiness of mathematics teachers of state junior high schools in Cilacap Regency is included in the sufficient criterion. These conclusions are supported by the following components: the teachers'knowledge of the teaching of mathematics in Curriculum 2013, which is in the sufficient criterion; the teachers'efforts to improve their understanding of teaching mathematics in Curriculum 2013, which is in the insufficient criterion; the teachers'attitudes towards the implementation of Curriculum 2013, which is in the sufficient criterion; the planning the implementation of teaching mathematics in accordance with Curriculum 2013 which is in the sufficient criterion, and the availability of facilities that support the implementation of Curriculum 2013, which is in of the insufficient criterion.
\end{abstract}

Keywords: teacher readiness, learning of mathematics, Curriculum 2013

How to Cite: Khikayah, K. (2018). Kesiapan guru matematika sekolah menengah pertama dalam melaksanakan Kurikulum 2013. Pythagoras: Jurnal Pendidikan Matematika, 13(1), 43-51. doi:http://dx.doi.org/10.21831/pg.v13i1.21214

doi http://dx.doi.org/10.21831/pg.v13i1.21214

\section{PENDAHULUAN}

Pendidikan merupakan sebuah proses yang berlangsung sepanjang hidup manusia. Seiring dengan perkembangan zaman yang semakin maju, yang ditandai dengan berbagai macam perubahan menghadirkan tantangan bagi dunia pendidikan untuk meningkatkan mutu lulusan, agar lulusan dapat tetap bertahan di era sekarang 
dan yang akan datang. Upaya dilakukan secara terus menerus untuk melakukan perubahan yang cukup mendasar untuk mempersiapkan peserta didik agar dapat bersaing dengan negara-negara lain.

Dari sejumlah perbaikan yang dilakukan untuk meningkatkan mutu pendidikan adalah dilakukannya penyempurnaan kurikulum. Kurikulum merupakan cakupan program yang dikembangkan (Pugach, 2006, p.128) yang berkatian kegiatan dan pengalaman belajar (Marsh, 2008, p.7). Kurikulum mencakup seperangkat rencana dan pengaturan mengenai tujuan, isi, dan bahan pelajaran serta cara yang digunakan sebagai pedoman penyelenggaraan kegiatan pembelajaran (Republik Indonesia, 2003).

Pada tahun 2013 pemerintah Republik Indonesia melakukan penyempurnaan kurikulum dengan memberlakukan kurikulum baru bernama Kurikulum 2013 atau K13 (Mendikbud RI, 2013). Adanya penyempurnaan dan perubahan yang mendasar berkaitan dengan kurikulum secara langsung menuntut berbagai perubahan pada komponen pendidikan. Harapannya, seluruh pihak terkait implementasi kurikulum mengetahui dan memahami komponen-komponen yang telah mengalami penyempurnaan atau perubahan tersebut.

Upaya untuk mengimplementasikan kurikulum 2013 dilakukan dengan melaksanakan sosialasi kepada semua pihak yang terlibat dalam pelaksanaannya. Salah satu komponen penting dalam pelaksanaan kurikulum tersebut adalah guru. Namun, sosialiasasi yang sudha dilaksanakan sepertinya belum mencapai hasil maksimal. Akibatnya, muncul berbagai persoalan di kalangan guru dalam mengimplementasikan kurikulum 2013. Beberapa kendala teknis terkait pelaksanaan kurikulum 2013 masih saja ditemukan. Kendala-kendala tersebut antara lain berkaitan dengan perencanaan, pelaksanaan, dan penilaian pembelajaran, serta ketersediaan sarana pendukung (Retnawati, 2015; Retnawati, Djidu, Kartianom, Apino, \& Anazifa, 2018; Retnawati, Hadi, \& Nugraha, 2016; Retnawati, Munadi, Arlinwibowo, Wulandari, \& Sulistyaningsih, 2017).

Setidaknya ada dua faktor utama yang berpengaruh terhadap keberhasilan Kurikulum 2013. Pertama, penentu, yaitu kesesuaian kompetensi pendidik dan tenaga kependidikan (PTK) dengan kurikulum dan buku teks. Kedua, faktor pendukung yang terdiri dari tiga unsur; ketersediaan buku sebagai bahan ajar dan sumber belajar yang mengintegrasikan standar pembentuk kurikulum; penguatan peran pemerintah dalam pembinaan dan pengawasan; dan penguatan manajemen dan budaya sekolah.

Guru memiliki peranan yang besar dalam menentukan keberhasilan pendidikan, karena guru memegang peranan dalam proses pembelajaran di kelas (Handal \& Herrington, 2003, p.65). Jika ditinjau dari kompetensinya, maka kesiapan adalah salah satu aspek penting di dalamnya. Kesuksesan implementasi Kurikulum 2013 sangat dipengaruhi oleh kesiapan guru yang akan menerapkan dan mengaktualisasikan kurikulum. Kesiapan guru dalam proses belajar mengajar sangat penting dalam menghasilkan dan menciptakan pengajaran dan metode pembelajaran yang efektif. (Jusoh, 2012, p.1). Guru perlu mengetahui konten yang diajarkan, menyusun rencana pelajaran yang bermakna bagi peserta didik, mengorganisasi materi yang diajarkan dan menyusun rencana cadangan (Allen, 2007). Dengan kata lain, guru dikatakan memiliki kesiapan dalam melaksanakan Kurikulum 2013 jika guru memiliki kesiapan mental, pengetahuan, sarana dan prasarana, dan kesiapan melaksanakan pembelajaran.

Kesiapan atau readiness menurut Cronbach (Soemanto, 2003, p.191) adalah segenap sifat atau kekuatan yang membuat seseorang dapat bereaksi dengan cara tertentu. Kesiapan juga merupakan keseluruhan kondisi seseorang yang membuatnya mampu untuk memberi respon/jawaban dengan cara tertentu terhadap suatu situasi (Slameto, 2010, p.113) merupakan. Penyesuaian kondisi pada suatu saat akan berpengaruh pada atau kecenderungan untuk memberi respons. Kondisi mencakup setidak-tidaknya 3 aspek, yaitu kondisi fisik, mental dan emosional; kebutuhan-kebutuhan, motif dan tujuan; keterampilan, pengetahuan dan pengertian lain yang telah dipelajari.

Menurut Bloom dalam Anderson \& Krathwohl (2001, p.27), pengetahuan bisa diartikan kemampuan seseorang untuk mengungkapkan kembali apa yang diketahuinya dalam bantuk bukti jawaban baik lisan maupun tulis. Sedangkan pengetahuan menurut Hunt (2003, p.102), pengetahuan adalah karakteristik seseorang yang mempengaruhi potensi perilaku seseorang. Karena pengetahuan sendiri, tidak dapat langsung diamati, maka harus disimpulkan dari pengamatan kinerja pada tes. Berdasarkan beberapa pendapat di atas, pengetahuan guru terhadap pembelajaran matematika merupakan kemampuan guru untuk mengungkapkan kembali apa yang 
diketahuinya dalam bentuk bukti jawaban baik lisan maupun tulisan, dan bukti tersebut merupakan suatu reaksi dari suatu stimulus yang berupa pertanyaan baik lisan atau tulisan mengenai pembelajaran Matematika Kurikulum 2013.

Pengertian sikap menurut Aiken dalam Gable (2013, p.7) sebagai kecenderungan untuk merespon secara positif atau negatif terhadap obyek, situasi, konsep, atau pribadi adalah konsep dari sikap. Kecenderungan itu akan memberikan pengaruh terhadap komponen kognitif, afektif dan performa. Komponen kognitif adalah apa yang dipercaya, atau diketahui, komponen afektif yaitu emosi dan motivasi, dan komponen performa yaitu perilaku atau kecenderungan bertindak. Definisi lain mengenai sikap menurut Beyene \& Tizazu (2010, p.91), yaitu titik pandang seseorang yang memegang teguh sebuah ide atau obyek dalam kehidupan sehari-hari. Semua orang dapat mengembangkan sikap positif atau negatif menurut obyek atau idenya. Lebih jauh dijelaskan bahwa keefektifan sebuah program bergantung pada sikap orang-orang terhadap program itu, salah satu bagian dari implementasi sebuah program. Sedangkan pengertian sikap menurut Nel, et al (2011, p.4) didefinisikan sebagai kecenderungan untuk bereaksi secara positif atau negatif terhadap objek tertentu, baik itu orang, ide atau situasi. Sikap sering berhubungan dalam beberapa cara untuk berinteraksi dengan orang lain dan merupakan link penting antara psikologi sosial dan kognitif. Sikap menurut Raved \& Assaraf (2011), dibagi menjadi tiga kategori yaitu afektif, perilaku dan kognitif.

Berdasarkan uraian tersebut, dapat disimpulkan bahwa sikap merupakan kecenderungan seseorang untuk menerima, atau menolak sesuatu, konsep, kumpulan ide, atau kelompok individu. Secara lebih spesifik, sikap guru dalam pembelajaran matematika Kurikulum 2013 dapat dideskripsikan sebagai respon guru terhadap pembelajaran matematika Kurikulum 2013 yang ditunjukkan melalui pernyataan favorable dan unfavorable yang memuat komponen kognitif, afektif, dan konatif. Komponen kognitif berkaitan dengan pengetahuan, keyakinan serta penilaian guru terhadap tujuan (SKL), materi (standar isi), pendekatan (standar proses), serta penilaian (standar penilaian), afektif berkaitan dengan emosi atau perasaan yang timbul dan konatif berkaitan dengan kebiasaan atau kecenderungan.

Menurut Peraturan Menteri Pendidikan Nasional 24 tahun 2007, sarana adalah perlengkapan pembelajaran yang dapat dipindah-pindah, terdiri dari perabot, peralatan pendidikan, media pendidikan, buku, dan sumber belajar lainnya, teknologi informasi dan komunikasi, sedangkan prasarana adalah fasilitas dasar untuk menjalankan fungsi sekolah, terdiri dari lahan, bangunan, ruang-ruang, serta instalasi daya dan jasa. Menurut Mulyasa (2014, p.53) selain kesiapan guru yang matang, kunci sukses Kurikulum 2013 ada pada lingkungan yang kondusif baik fisik maupun non fisik. Ketersediaan sarana dan prasarana dalam penelitian ini difokuskan pada sarana dan prasarana yang berkaitan dengan Kurikulum 2013, antara lain ketersediaan buku sebagai bahan ajar dan sumber belajar lainnya, media seperti LCD, laboratorium komputer, akses internet serta dukungan sekolah terhadap pengadaan sarana dan prasarana demi menunjang kesiapan guru dalam pelaksanaan pembelajaran matematika Kurikulum 2013.

Karena besarnya peranan guru dalam kesuksesan implementasi kurikulum 2013, maka perlu dilakukan penelitian memotret sejauh mana kesiapan guru dalam mengimplementasikannya. Sejumlah penelitian telah dilakukan di beberapa daerah seperti yang dilakukan oleh Retnawati (2015), Rusindrayanti dan Santoso (2015), Syukriya, Herpratiwi, dan Yulianti (2016), dan penelian Wati dan Jailani (2016) untuk memotret kesiapan maupun kendala guru dalam mengimplementasikan kurikulum 2013. Namun karena penelitian-tersebut dilakukan di suatu daerah tertentu, maka hasilnya tentu belum dapat digeneralisasikan pada daerah lainnya. Oleh karena itu, penelitian ini bertujuan untuk mengungkap kesiapan guru matematika SMP negeri di Kabupaten Cilacap, Jawa Tengah dalam mengimplementasikan Kurikulum 2013.

\section{METODE}

Penelitian ini merupakan penelitian deskriptif eksploratif yang dilakukan untuk mengetahui kesiapan guru matematika SMP negeri di Kabupaten Cilacap, dalam mengmplimentasikan Kurikulum 2013. Pendekatan yang digunakan adalah kuantitatif dan kualitatif.

Penelitian ini dilaksanakan di Kabupaten Cilacap dengan jumlah populasi sebanyak 264 orang guru matematika yang tersebar di 84 SMP negeri. Berdasarkan peringkat UN tahun sebelumnya, 84 SMP Negeri dikelompokkan ke dalam kategori A, B, C, D, dan E. Kemudian diperoleh 16 sekolah yang mewakili masingmasing kategori. Dari masing-masing sekolah diwakili oleh guru yang mengajar di kelas 7 dan 8 sehingga didapatkan sampel sebanyak 31 guru. 
Penelitian ini mengungkapkan kesiapan guru matematika SMP negeri di Kabupaten Cilacap dalam melaksanakan Kurikulum 2013, yang terdiri dari kesiapan pengetahuan guru, upaya yang dilakukan guru dalam meningkatkan pemahaman, sikap guru terhadap pelaksanaan Kurikulum 2013, perencanaan pembelajaran serta sarana dan prasarana penunjang pelaksanaan Kurikulum 2013.

Instrumen yang digunakan dalam penelitian ini adalah angket, panduan wawancara, panduan observasi, dan dokumentasi RPP. Instrumen angket digunakan untuk memperoleh data tentang pengetahuan guru, upaya guru, sikap guru, serta ketersediaan sarana dan prasarana. Instrumen panduan wawancara dan observasi digunakan untuk memperdalam atau memperkuat hasil dari angket.

Data yang telah dikumpulkan dianalisis secara deskriptif, yaitu dengan mendeskripsikan dan memaknai data dari masing-masing variabel yang diteliti baik data kuantitatif maupun data kualitatif. Sebelum dianalisis, dilakukan proses kuantifikasi dari angket dan observasi, selanjutnya data tersebut dianalisis menggunakan statistik deskriptif.

Tabel 1. Pengkategorian Tingkat Kesiapan

\begin{tabular}{cc}
\hline Interval Nilai & Kriteria \\
\hline $90<\mathrm{X}$ & Sangat Baik \\
$75<\mathrm{X} \leq 90$ & Baik \\
$60<\mathrm{X} \leq 75$ & Cukup Baik \\
$50<\mathrm{X} \leq 60$ & Kurang \\
$\mathrm{X} \leq 50$ & Sangat Kurang \\
\hline
\end{tabular}

Keterangan $\mathrm{X}=$ Nilai Responden

Data hasil wawancara, dianalisis dengan analisis kualitatif. Teknik analisis kualitatif yang digunakan adalah model interaktif dari Miles dan Huberman (Miles, Huberman, \& Saldana, 2014). Dalam melakukan analisis data ada tiga kegiatan yang dilakukan secara bersamaan, yaitu reduksi data, penyajian data, dan penarikan kesimpulan.

Penentuan tingkat kesiapan guru dan daya dukung dalam hal ini sarana prasarana untuk masing-masing indikator atau setiap instrumen dilakukan dengan mengkategorikannya kedalam lima kriteria, dengan rumusan kriteria diadaptasi dari Peraturan Menteri Negara Pendayagunaan Aparatur Negara dan Reformasi Birokrasi Nomor 16 Tahun 2009 tentang Jabatan Fungsional Guru dan Angka Kreditnya dan dapat dilihat pada Tabel 1.

\section{HASIL DAN PEMBAHASAN}

\section{Hasil}

Berdasarkan hasil pengumpulan dan analisis data yang diperoleh dari 31 guru matematika di Kabupaten Cilacap, diperoleh gambaran mengenai kesiapan guru dalam mengimplementasikan kurikulum 2013 sebagai berikut.

\section{Pengetahuan Guru Mengenai Kurikulum 2013}

Pemberlakuan Kurikulum 2013 merupakan bagian dari upaya pemerintah untuk mempersiapkan generasi menghadapi tantangan abad 21 ini. Salah satu aspek yang diperkuat dalam pelaksanaan kurikulum 2013 adalah nilai-nilai karakter dan religiusitas (Parker, 2017). Akan tetapi, tujuan yang direncanakan dalam kurikulum akan tercapai apabila implementasinya sudahh maksimal. Oleh karena itu, implementasi kurikulum harus didukung oleh pengetahuan guru dalam mengimplementasikannya. Pengetahuan guru sangat penting karena pengetahuan dapat mempengaruhi potensi perilaku seseorang (Hunt, 2003, p.102). Jika pengetahuan guru baik tentang pelaksanaan, maka akan potensi perilaku guru itu sendiri dalam melaksanakan kurikulum 2013 juga akan baik.

Tabel 2. Pengetahuan Guru

\begin{tabular}{ccc}
\hline Kriteria & f & Persentase \\
\hline Sangat Baik & 2 & 6 \\
Baik & 7 & 23 \\
Cukup & 17 & 55 \\
Kurang & 4 & 13 \\
Sangat Kurang & 1 & 3 \\
\hline
\end{tabular}

Pengetahuan guru mengenai kurikulum 2013 diperoleh dari hasil isian angket. Berdasarkan hasil analisis diperoleh nilai tertinggi sebesar 95 dan nilai terendah sebesar 55. Hasil analisis skor pengetahuan guru mengenai kurikulum 2013 dapat dilihat pada Tabel 2. Berdasarkan angket yang diberikan kepada responden dapat disimpulkan bahwa lebih dari sebagian besar responden $(55 \%)$ telah memiliki pengetahuan yang cukup baik. Hal ini menandakan bahwa pengetahuan guru matematika SMP Negeri Di Kabupaten Cilacap tentang Kurikulum 2013 kategori cukup.

Berdasarkan hasil wawancara, ada kegiatan selama semester satu yang diselenggarakan yaitu kegiatan IN ON, yaitu kegiatan pendampingan oleh guru-guru yang ditunjuk oleh Dinas Pendidikan Kabupaten untuk mendampingi kegiatan pembelajaran Kurikulum 2013 di masing-masing MGMP Kecamatan sehingga 
guru telah dibiasakan dengan pembelajaran matematika Kurikulum 2013. Kegiatan ini diserahkan kepada MGMP masing-masing kecamatan untuk mengadakan kegiatan ini dan mengatur jadwalnya. Setiap ada kebijakan baru yang dikeluarkan biasanya akan saling ditularkan dalam kegiatan IN ON ini, kegiatan IN merupakan kegiatan guru menyusun RPP dengan bimbingan guru yang telah ditunjuk oleh Dinas Kabupaten, kemudian kegiatan ON adalah kegiatan supervisi/pendampingan pembelajaran di dalam kelas. Kegiatan IN biasanya dilakukan 1-2 kali, sedangkan kegiatan ON dilakukan 2-3 kali dan setelah itu dilakukan refleksi untuk perbaikan. Dari hasil wawancara juga didapatkan bahwa kegiatan ini sangat banyak membantu guru untuk memahami pelaksanaan pembelajaran matematika Kurikulum 2013 yang sesuai dengan landasan kebijakan. Pengetahuan guru tentang materi Matematika Kurikulum 2013 memang kurang baik, dari hasil wawancara guru menyatakan bahwa pelaksanaan Kurikulum 2013 hanya satu semester dan guru sudah banyak yang lupa karena semester ini sudah tidak melaksanakan Kurikulum 2013.

\section{Upaya Guru untuk meningkatkan Pemahaman}

Pengembangan dan pembaharuan kurikulum seharusnya diiringi dengan pengembangan dan pembaharuan pengetahuan dan informasi kepada guru (Posch, 1996). Namun, hal tersebut belum terlihat pada hasil penelitian ini. Informasi mengenai upaya guru untuk meningkatkan pemahaman terkait Kurikulum 2013 diperoleh dari pengumpulan data dengan menggunakan dua instrumen. Instrumen pertama, yaitu upaya/kegiatan untuk meningkatkan pemahaman, nilai tertinggi yang dicapai oleh responden sebesar 72 dan nilai terendah sebesar 30. Instrumen kedua yaitu kelengkapan dokumen pendukung pemahaman nilai tertinggi yang dicapai oleh responden sebesar 76 dan nilai terendah sebesar 20 . Hasil analisis upaya guru matematika SMP Negeri di Kabupaten Cilacap meningkatkan pemahaman dapat dilihat pada Tabel 3.

Berdasarkan angket yang diberikan kepada responden dapat disimpulkan bahwa upaya yang dilakukan dalam meningkatkan pemahaman masuk kategori kurang. Berdasarkan hasil wawancara, sebagian besar guru memperoleh dokumen tersebut saat mengikuti kegiatan sosialisasi dan kegiatan lanjutan yang diselenggarakan oleh Dinas Kabupaten Cilacap yaitu kegiatan IN ON Kurikulum 2013. Peraturan Menteri yang terbaru juga selalu diberikan oleh Guru Sasaran yang ditunjuk untuk melakukan kegiatan pendamping- an dan supervisi pembelajaran matematika di kelas, dan hal ini dilaksanakan sekitar 2-3 kali dalam satu semester. Secara konseptual, para guru matematika SMP tidak terlalu memahami keseluruhan isi dari peraturan menteri tersebut, mereka hanya sekedar mengoleksi di laptop akan tetapi kurang memahami isinya.

Tabel 3. Upaya Guru untuk Meningkatakan Pemahaman

\begin{tabular}{ccc}
\hline Kriteria & f & Persentase \\
\hline Sangat Baik & 0 & 0 \\
Baik & 0 & 0 \\
Cukup & 5 & 16 \\
Kurang & 9 & 29 \\
Sangat Kurang & 17 & 55 \\
\hline
\end{tabular}

Sebagian besar guru berdasarkan wawancara menyatakan bahwa mereka lebih membutuhkan pelatihan yang berkelanjutan yang diselenggarakan oleh Dinas Pendidikan. Kegiatan pelatihan atau seminar mengenai pembelajaran matematika yang inovatif sangat jarang diikuti oleh guru sehingga dalam melaksanakan pembelajaran guru kurang menggunakan model pembelajaran yang bervariasi.

Pendidikan dan pelatihan, serta pendampingan merupakan hal yang mendukung implementasi Kurikulum baru. Hal tersebut sebagaimana hasil penelitian Koo (2008, p.1) yang menyatakan bahwa mayoritas guru membutuhkan pelatihan, dan pendampingan dalam implementasi pembelajaran online yang merupakan suatu hal yang baru. Hal ini sejalan dengan hasil penelitian Wibowo (2014, p.66) yang menyatakan bahwa sosialisasi kurikulum baru kurang bisa dipahami oleh guru. Informasi tentang

Kurikulum 2013 juga bisa diperoleh melalui internet, $\mathrm{CD}$, buku, media cetak lainnya. Namun secara umum masih banyak guru matematika yang tidak mengikuti kegiatan/upaya untuk meningkatkan pemahaman terhadap Kurikulum 2013. Secara keseluruhan upaya guru dalam meningkatkan pemahaman pelaksankana pembelajaran matematika Kurikulum 2013 termasuk kategori kurang, dengan upaya/kegiatan yang dilaksanakan masuk kategori kurang dan kelengkapan dokumen masuk kategori cukup.

\section{Sikap Guru}

Selain pengetahuan, sikap guru merupakan salah satu hal penting yang dapat mempengaruhi kualitas pendidikan (Dilekli \& Tezci, 2016). Adapun hasil analisis data mengenai sikap guru memberikan hasil sebagai berikut. Nilai tertinggi yang dicapai oleh guru sebesar 96 dan nilai 
terendah sebesar 60. Adapun hasil analisi sikap guru matematika SMP Negeri di Kabupaten Cilacap dalam melaksanakan Kurikulum 2013 dapat dilihat pada Tabel 4.

Tabel 4. Sikap Guru

\begin{tabular}{ccc}
\hline Kriteria & f & Persentase \\
\hline Sangat Baik & 1 & 3 \\
Baik & 8 & 26 \\
Cukup & 20 & 65 \\
Kurang & 2 & 6 \\
Sangat Kurang & 0 & 0 \\
\hline
\end{tabular}

Berdasarkan angket yang diberikan kepada responden dapat disimpulkan bahwa lebih dari sebagian besar responden (65\%) memiliki sikap yang cukup baik terhadap pelaksanaan Kurikulum 2013. Hal ini menandakan bahwa sikap guru matematika SMP Negeri Di Kabupaten Cilacap tentang Kurikulum 2013 kategori cukup dan mendukung pelaksanaan Kurikulum 2013 akan tetapi dengan beberapa catatan. Dari hasil angket, butir yang tidak didukung pelaksanaannya oleh guru adalah butir tentang menerapkan penilaian sepenuhnya oleh guru. Berdasarkan hasil wawancara, penilaian Kurikulum 2013 terkesan terlalu banyak dan membebani guru, sehingga kadang guru hanya fokus melaksanakan penilaian dan mengabaikan ketuntasan materi pembelajaran. Yang paling banyak merasa keberatan, dari hasil wawancara adalah mengenai penilaian sikap spiritual dan sosial. Sikap guru terhadap pendekatan pembelajaran yaitu pendekatan saintifik juga mendukung akan tetapi guru berharap bahwa tidak semua materi bisa untuk menggunakan pendekatan saintifik, jadi guru berharap bahwa pendekatan saintifik bukan suatu harga mati dalam pembelajaran sehingga banyak guru dalam kenyataannya tidak mengajar menggunakan pendekatan saintifik disesuaikan dengan materi pembelajarannya. Hal ini sesuai dengan hasil penelitian Purnomo (2017) yang menemukan bahwa pemahaman dan keyakinan guru mengenai suatu strategi pembelajaran tidak selalu sejalan dengan apa yang mereka lakukan di dalam kelas.

\section{Perencanaan Pembelajaran}

Kesiapan guru dalam perencanaan pembelajaran sangat dibutuhkan agar pelaksanaannya berjalan dengan baik. Hal tersebut dikarenakan adanya hubungan antara perencanaan yang dibuat oleh guru dengan hasil yang diperoleh siswa (Ritzema, Deunk, Bosker, \& van Kuijk, 2016). Adapun hasil analisis terkait kesiapan guru dalam merencanakan pembelajaran yang sesuai dengan kurikulum 2013 adalah sebagai berikut Tabel 5 . Untuk melaksanakan pembelajaran Matematika, guru harus memiliki dokumen RPP yang sesuai dengan Kurikulum 2013. Di lapangan, dari hasil telaah dokumen RPP, kesiapan merencanakan guru secara umum masuk kategori cukup, dengan perincian sebanyak $13 \%$ guru sangat baik, $61 \%$ responden baik, $10 \%$ responden kategori cukup, serta $16 \%$ kategori sangat kurang dalam merencanakan RPP.

Tabel 5. Perencanaan Pembelajaran

\begin{tabular}{lcc}
\hline \multicolumn{1}{c}{ Kriteria } & f & Persentase \\
\hline Sangat Baik & 4 & 13 \\
Baik & 19 & 61 \\
Cukup & 3 & 10 \\
Kurang & 0 & 0 \\
Sangat Kurang & 5 & 16 \\
\hline
\end{tabular}

Dari hasil telaah dokumen kualitas RPP, meskipun rata-rata masuk kategori cukup, akan tetapi untuk butir nomor ciri khas Kurikulum 2013 yaitu butir no 26-36, masuk kategori sangat kurang. Yang menjadi ciri khas Kurikulum 2013 malah yang paling banyak tidak dilaksanakan dalam menyusun RPP yaitu butir tentang pendekatan saintifik dan model pembelajaran yang inovatif. Sehingga meskipun perencanaan RPP kategori cukup, akan tetapi ciri khas dari Kurikulum 2013 ini tidak terlaksana dengan baik karena masuk kategori sangat kurang. Berdasarkan hasil wawancara, pada umumnya guru membuat RPP yang sebisa mungkin sesuai dengan Kurikulum 2013 karena adanya kegiatan pendampingan IN ON tersebut meskipun guru masih merasa hanya menggugurkan kewajiban penggunaan pendekatan saintifik tanpa tahu makna sebenarnya dari langkah-langkah yang ada pada pendekatan saintifik. Langkah dalam scientific method pada dasarnya adalah mengungkap realita berupa fenomena melalui pengamatan/observasi (Keyes, 2010, p.12) Langkah-langkah dalam scientific method terdiri dari observasi, menyusun hipotesis untuk menjelaskan fenomena, memprediksikan fenomena lain menggunakan hipotesis, membuat tes eksperimen atau validasi (Fulton \& Sabatino, 2008, p.8).

Pengetahuan yang baik tentang pelaksanaan pembelajaran matematika Kurikulum 2013 akan mempengaruhi penyusunan RPP. Upaya pengembangan RPP secara mandiri memang telah dilakukan oleh guru. Pengembangan yang dilakukan adalah mereka membuat secara bersama pada kegiatan MGMP masing-masing kecamatan kemudian diubah dan di revisi sendiri 
untuk kegiatan IN dan ON pendampingan Kurikulum 2013 yang disesuaikan dengan sumber daya, sarana dan prasarana, kondisi siswa sehingga sebagian besar menyusun RPP secara mandiri.

\section{Ketersediaan Sarana dan Prasarana}

Hal yang tidak kalah pentingnya dalam pelaksanaan kurikulum 2013 adalah sarana dan prasaran pendukung. Berbagai persoalan bisa muncul akibat sarana prasaran yang tidak memadai. Dalam suatu penelitian yang dilakukan oleh Retnawati, et al. (2017) menemukan adanya berbagai permasalahan dalam pelaksanaan ujian nasional berbasis komputer yang disebabkan sarana prasarana yang kurang memadai. Adapun hasil analisis data terkait ketersediaan sarana dan prasarana pada penelitian ini dapat dilihat pada Tabel 6.

Tabel 6. Ketersediaan Sarana dan Prasarana

\begin{tabular}{ccc}
\hline Kriteria & f & Persentase \\
\hline Sangat Baik & 0 & 0 \\
Baik & 4 & 13 \\
Cukup & 4 & 13 \\
Kurang & 9 & 29 \\
Sangat Kurang & 14 & 45 \\
\hline
\end{tabular}

Berdasarkan angket yang diberikan kepada responden dapat disimpulkan bahwa rata-rata responden $(45 \%)$ memiliki kesiapan sarana dan prasarana kategori sangat kurang. Akan tetapi, rata-rata kesiapan sarana dan prasarana SMP Negeri Di Kabupaten Cilacap dalam menunjang pelaksanaan Kurikulum 2013 masuk kategori kurang. Berdasarkan wawancara, meskipun buku siswa kategori memiliki, tapi datangnya sangat terlambat, bahkan untuk buku siswa kelas 8 datang disaat mendekati UAS semester 1 , dan pemakaian buku siswa juga dua anak satu buku. Sebelum buku datang, terpaksa guru mencetak sendiri buku siswa maupun buku guru yang diberikan pada saat pelatihan. Untuk sumber lain yang disediakan oleh perpustakaan pun sama sekali tidak ada, guru hanya menggunakan buku Kurikulum lama sebagai sumber lain. Untuk ketersediaan komputer, banyak sekolah yang belum cukup memadai, banyak komputer yang sudah rusak dan hanya sekolah kota yang memiliki komputer cukup memadai dan pemakaiannya juga satu komputer untuk dua siswa, dan akses internet juga telah ada di seluruh sekolah akan tetapi dari segi layanan kurang memadai, misalnya jaringannya lemah.

Berdasarkan uraian tersebut, diperoleh gambaran secara umum kesiapan guru mate- matika SMP Negeri di Kabupaten Cilacap dari segi pengetahuan guru, upaya yang dilakukan guru dalam meningkatkan pemahaman Kurikulum 2013, sikap guru, kesiapan sarana dan prasarana, serta kesiapan merencanakan pembelajaran masuk kategori cukup. Artinya, masih perlu upaya unutk meningkatkan kesiapan guru.

\section{SIMPULAN}

Berdasarkan hasil analisi data kesiapan guru matematika SMP negeri di kabupaten Cilacap yang telah diuraikan di atas, diperoleh beberapa kesimpulan. Pertama, sebagian besar guru masih belum memiliki kesiapan yang baik ditinjau dari pengetahuan mereka terkait Kurikulum 2013. Kedua, pengetahuan yang masih belum baik tersebut tidak didukung oleh sikap dan upaya untuk meningkatkan pengetahuan mereka. Ketiga, ketersediaan sarana dan prasarana penunjang masih kurang.

Temuan dari penelitian ini memerlukan tindak lanjut dari berbagai kalangan, termasuk sekolah, guru, dan pengambil kebijakan. Pertama, sosialisasi dan pelatihan diperlukan guru secara merata dan menyeluruh, terarah dan terprogram dengan baik dilanjutkan dengan monitoring dan evaluasi secara teratur dan terarah. Pemangku kebijakan berperan penting dalam kegiatan ini. Kedua, guru hendaknya memiliki pengetahuan yang baik dalam melaksanakan Kurikulum 2013, sehingga tujuan Kurikulum yang dikehendaki dapat tercapai.

\section{DAFTAR PUSTAKA}

Allen, T. (2007). Methods for success as a middle school science teacher. Science Scope, 31(1), 18.

Anderson, L.W \& Krathwohl, D. R. (2001). A taxonomy for learning, teaching, and assesing: a revision of bloom's taxonomy of educational objectives. New York, NY: Addison Wesley Longman, Inc

Beyene, G \& Tizazu,Y. (2010). Attitudes of teachers towards inclusive education in Ethiopia. Ethiopia Journal Education And Science, 6(1). Diambil dari https://www.ajol.info/index.php/ejesc/arti cle/view/65383

Dilekli, Y., \& Tezci, E. (2016). The relationship among teachers' classroom practices for teaching thinking skills, teachers' selfefficacy towards teaching thinking skills and teachers' teaching styles. Thinking 
Skills and Creativity, 21, 144-151. https://doi.org/10.1016/j.tsc.2016.06.001

Fulton, J. P., \& Sabatino, L. (2008). Using the scientific method to motivate biology students to study precalculus. Primus, 18(1), 5-21. Retrived from https://www.tandfonline.com/doi/abs/10.1 080/10511970701745007

Gable, R.K, McCoach, D.B, \&Madura, J.P. (2013). Instrument development in the affective domain. New York, NY: Springer Science Business Media

Handal, B., \& Herrington, A. (2003). Mathematics teachers' beliefs and curriculum reform. Mathematics education research journal, 15(1), 59-69. Diambil dari https://link.springer.com/article/10.1007/ BF03217369

Hunt, D.P. (2003). The concept of knowledge and how to measure it. Journal of intelectuall capital, 4(1), 100-113. Diambil dari https://www.emeraldinsight.com/doi/pdf/ $10.1108 / 14691930310455414$

Jusoh, R. (2012). Effects of teachers readiness in teaching and learning of entrepreneurship education in primary schools. International Interdisciplinary Journal of Education, 1(1027), 1-5. Diambil dari https://platform.almanhal.com/GoogleSch olar/Details/?ID=2-42736

Keyes, G. (2010). Teaching the scientific methods in the social science. The Journal of the Effective Teaching, 10(2), 18-28. Diambil dari https://eric.ed.gov/?id=EJ1092185

Koo, A. C. (2008). Factors affecting teachers' perceived readiness for online collaborative learning: a case study in Malaysia. Journal of educational technology \& society, 11 (1), 266-278. Diambil dari https://www.jstor.org/stable/pdf/jeductech soci.11.1.266.pdf

Marsh, C. J. (2008). Key concept for understanding curriculum. Great Britain: Routledge.

Mendikbud RI. (2013). Peraturan menteri pendidikan dan kebudayaan Republik Indonesia nomor 81A tahun 2013 tentang implementasi kurikulum. Jakarta: Kementerian Pendidikan dan Kebudayaan Republik Indonesia.
Miles, M. B., Huberman, A. M., \& Saldana, J. (2014). Qualitative data analysis: a methods sourcebook (3rd ed.). Thousand Oaks, CA: SAGE. Diambil dari https://goo.gl/2nSrNr

Nel, N., Müller, H., Hugo, A., Helldin, R., Bäckmann, Ö., Dwyer, H., \& Skarlind, A. (2011). A comparative perspective on teacher attitude-constructs that impact on inclusive education in South Africa and Sweden. South African Journal of Education, 31(1). Diambil dari https://www.ajol.info/index.php/saje/articl e/view/63492

Parker, L. (2017). Religious environmental education? the new school curriculum in Indonesia. Environmental Education Research, 23(9), 1249-1272. https://doi.org/10.1080/13504622.2016.11 50425

Posch, P. (1996). Curriculum change and school sevelopment. Environmental Education Research, 2(3), 347-362. https://doi.org/10.1080/135046296002030 7

Pugach, M. C. (2006). Because teaching matters. USA: John Wiley \&Sons, Inc

Purnomo, Y. W. (2017). The complex relationship between teachers' mathematics-related beliefs and their practices in mathematics class. New Educational Review, 47(1), 200-210. https://doi.org/10.15804/tner.2017.47.1.16

Raved, L., \& Assaraf, O. B. Z. (2011). Attitudes towards science learning among 10thgrade students: A qualitative look. International Journal of Science Education, 33(9), 1219-1243. Diambil dari https://www.tandfonline.com/doi/abs/10.1 080/09500693.2010.508503

Republik Indonesia. (2003). Undang-Undang nomor 20 tahun 2003 tentang sistem pendidikan nasional. Jakarta: Kementerian Pendidikan Nasional.

Retnawati, H. (2015). Hambatan guru matematika sekolah menengah pertama dalam menerapkan kurikulum baru. Jurnal Cakrawala Pendidikan, 34(3), 390-403. https://doi.org/10.21831/cp.v3i3.7694

Retnawati, H., Djidu, H., Kartianom, K., Apino, E., \& Anazifa, R. D. (2018). Teachers' knowledge about higher-order thinking skills and its learning strategy. Problem of 
Education in the 21 st Century, 76(2), 215$230 . \quad$ Diambil dari http://oaji.net/articles/2017/457-

1524597598.pdf

Retnawati, H., Hadi, S., \& Nugraha, A. C. (2016). Vocational high school teachers' difficulties in implementing the assessment in curriculum 2013 in Yogyakarta province of Indonesia. International Journal of Instruction, 9(1), 33-48. https://doi.org/10.12973/iji.2016.914a

Retnawati, H., Hadi, S., Nugraha, A. C., Arlinwibowo, J., Sulistyaningsih, E., Djidu, H., ... Iryanti, H. D. (2017). Implementing the computer-based national examination in Indonesian schools: the challenges and strategies. Problem of Education in the 21 st Century, 75(6), 612633. Diambil dari http://oaji.net/articles/2017/4571513710818.pdf

Retnawati, H., Munadi, S., Arlinwibowo, J., Wulandari, N. F., \& Sulistyaningsih, E. (2017). Teachers' difficulties in implementing thematic teaching and learning in elementary schools. The New Educational Review, 49(3), 201-212. https://doi.org/10.15804/tner.2017.48.2.16

Ritzema, E. S., Deunk, M. I., Bosker, R. J., \& van Kuijk, M. F. (2016). The relation between teacher-set performance goals and students' mathematical achievement. Studies in Educational Evaluation, 51, 1728.

https://doi.org/10.1016/j.stueduc.2016.08. 003
Rusindrayanti, R., \& Santoso, R. H. (2015). Implementasi Pendekatan Saintifik Mapel Matematika Kelas VII Tahun Pelajaran 2013/2014 pada Kurikulum 2013 DIY. PYTHAGORAS: Jurnal Pendidikan Matematika, 10(1), 80-94. Diambil dari http://journal.uny.ac.id/index.php/pythago ras/article/view/9112/pdf

Slameto. (2010). Belajar dan faktor-faktor yang mempengaruhinya (cetakan 5). Jakarta: Rineka Cipta.

Soemanto, W. (2003). Psikologi pendidikan. Jakarta: PT. Rineka Cipta

Syukriya, H., Herpratiwi, H., \& Yulianti, D. (2016). Evaluasi implementasi penilaian Kurikulum 2013. Jurnal Teknologi Informasi Komunikasi Pendidikan, 4(1). Diambil dari https://www.neliti.com/publications/1933 09/evaluasi-implementasi-penilaiankurikulum-2013

Wati, S., \& Jailani, J. (2016). Kesiapan guru matematika SMP di kabupaten Purworejo dalam implementasi kurikulum 2013. Pythagoras: Jurnal Pendidikan Matematika, 11(1), 77-90. https://doi.org/10.21831/pg.v11i1.9675

Wibowo, R \& Wutsqa, D. (2014). Evaluasi pelaksanaan kurikulum tingkat satuan pendidikan (KTSP) mata pelajaran matematika SMP di kota Yogyakarta. Jurnal Riset Pendidikan Matematika, 1(1), 58-68. Diambil dari https://journal.uny.ac.id/index.php/jrpm/ar ticle/view/2664 